\title{
RIGHT TO THE SUBURB? \\ RETHINKING LEFEBVRE AND IMMIGRANT ACTIVISM
}

GENEVIEVE CARPIO

University of Southern California

CLARA IRAZA' BAL

Columbia University

LAURA PULIDO

University of Southern California

\begin{abstract}
In the face of increasing migration by Latinos to suburbs and multi-scalar policiescriminalizing immigrants, municipalities are increasingly confronting the question, Who has the Right to the Suburb? We seek to better understand how the tensions between suburbanites and Latino immigrants are addressed by municipal governments as immigration enforcement is increasingly rescaled to the local level. Case studies of Maywood and Costa Mesa in Southern California suggest responses are by no means similar and can actually be contrasting, given the city's historical trajectories, socio-economic status, political leadership, and networks of activists. Suburban struggles are often assumed to be conservative and as a result are undertheorized as sites of liberatory struggle. While the urban realm remains the most visible stage of social movements, this paper suggests immigrant activism is increasingly being generated in suburbs, election-based organizing can be an effective gateway to municipal level change, and seeking to expand or constrict the Right to the City necessarily entails multi-scalar efforts.
\end{abstract}

In 2001, the cartoonist of syndicated comic strip La Cucaracha, Lalo Alcaraz, created a parody of Grant Wood's famous painting American Gothic (Figure 1). In the image, Alcaraz depicts a Latino couple as neighbors to the traditional mid-western couple from Wood's painting. While the Latino couple smiles at the viewer, the white farmer clutches the pitch fork defensively as both he and his companion stare warily at the seemingly out-of-place Latinos. The image by Alcaraz illustrates a dramatic demographic shift in the United States, in which Latino residents, immigrant and non-immigrant alike, are increasingly moving into "non-traditional" areas. These include new regions, as well as a shift from cities to suburbs (Singer, Hardwick, \& Brettell, 2008; Singer, 2004). This shift has increasingly generated pro- and anti-immigrant activism in suburbs. We argue these movements for contracted and expanded immigrant rights have been enabled through intersecting city, state, and federal policies, as well as local, regional, and national networks of activists. These dynamics often manifest at the municipal level. 


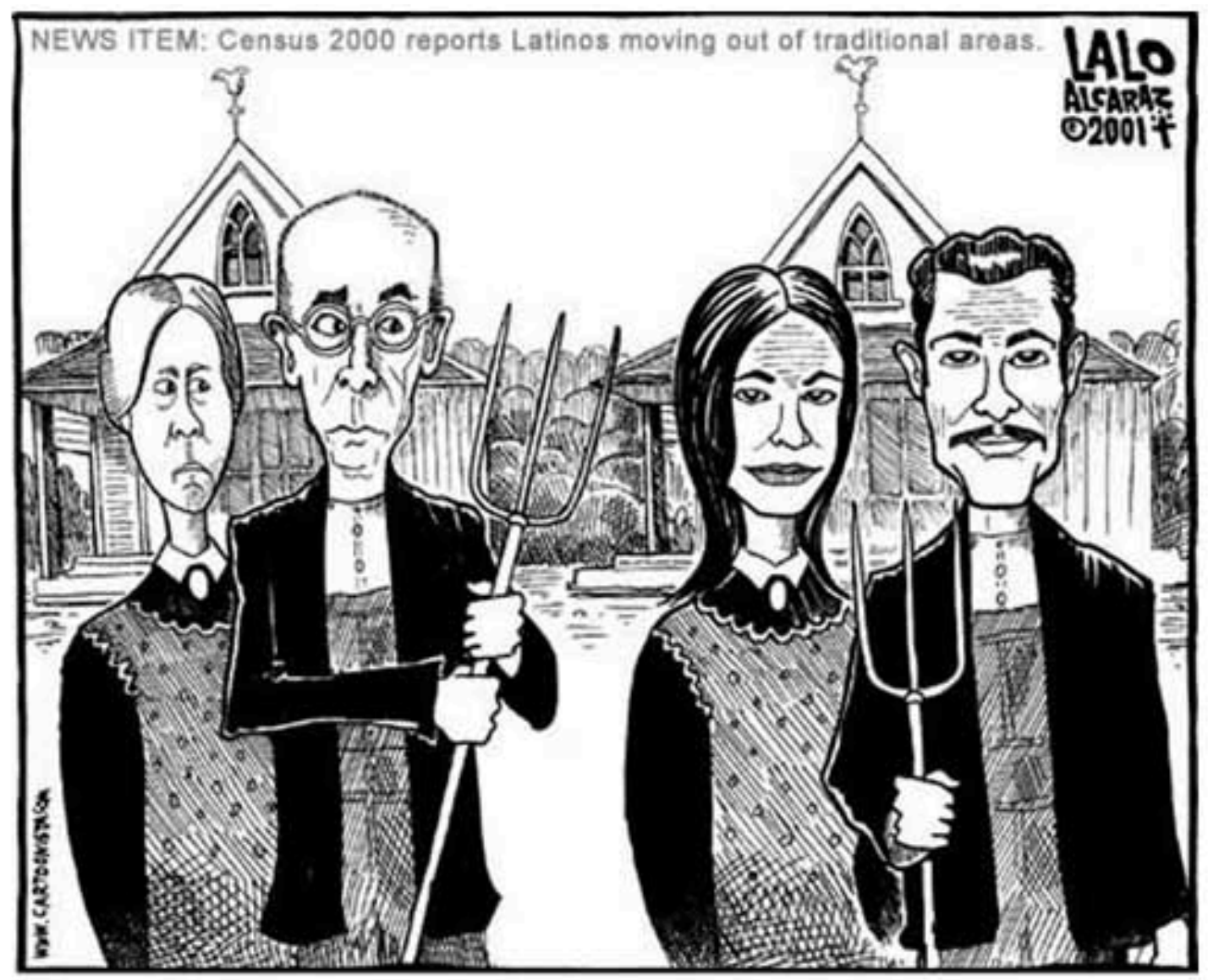

FIGURE 1

News Item: Census 2000 Reports Latinos Moving Out of Traditional Areas. From comic strip La Cucaracha, by Lalo Alcaraz, 2001

While the urban realm remains the most visible stage for immigrant rights activism, the suburbanization of Latinos has caused unique challenges that call for a reevaluation of approaches and theorizations of immigrant activism. Up until now, the phrase "Right to the City" has been often used as a rallying cry in the struggle for maximizing political access, claiming public space, and expanding spaces of citizenship. Conceived as the right to the urban by Henri Lefebvre (1996 [1968]), the concept has since been expanded by activists and scholars such as the Right to the City Alliance, Mark Purcell (2003), and DonMitchell (2003) as the right to political participation, public space, and self-governance. By assessing how this right is expanded and constricted for immigrants in two Southern California suburbs, this paper seeks to assess how Lefebvre's concept of Right to the City can be used to better understand pro and anti-immigrant activism and politics in the suburbs of Los Angeles.

Maywood in Los Angeles County and Costa Mesa in neighboring Orange County serve as divergent examples of suburbs struggling over immigration policy (VazquezCastillo, 2009; Cienfuegos, 2006). Both cities are residential hubs, historically white, and have experienced large growth in their domestic and international Latino populations over the past 20 years. While the predominantly Latino city of Maywood has declared itself a "Sanctuary City" in opposition to federal law, predominantly white Costa Mesa was reportedly the first city to partner with Federal Immigration and Customs Enforcement (ICE) to identify and deport unauthorized residents.1 For each suburb, local activism and electoral activism were gateways for municipal level change. By taking public stances for/against national immigration enforcement, powerful political and demographic shifts in City Councils, and demonstrations in public spaces, the two cities have come to represent the extremes of the immigration debate in the United States. Using the case II 
Right to the Suburb? Rethinking Lefebvre and Immigrant Activism II 187 studies of these two cities in Southern California, we seek to better understand how the tensions between suburbanites and Latino immigrants are addressed by local governments in the face of shifting ethnoracial geographies in the Los Angeles region. We argue that, in the face of increasing migration by Latinos to suburbs and multi-scalar policies criminalizing immigrants, municipalities and residents are confronting the question, Who has the Right to the Suburb?

\section{RIGHT TO THE CITY AND ITS TRANSFORMATIONS}

Since Henri Lefebvre coined the phrase "Right to the City" in 1968, it has sparked a "cry and a demand" for increased access to the urban and a reevaluation of citizenship in the city and beyond (Lefebvre, 1996, p. 168). It serves as a political platform for numerous organizations, including Strategic Action for a Just Economy in downtown Los Angeles, the Miami Worker Center, and the Environmental Health Coalition in San Diego, whose fundamental principles include the right to live in the city and the right to democratic participation and power (TIDES Foundation, 2007). Published shortly before the Parisian student uprisings in May 1968, The Right to the City is primarily concerned with "the problems of the city and urban society" (Lefebvre, 1996, p. 177). Lefebvre sees this as the struggle between industrialization and urbanization, and what he refers to as the tension between exchange value and use value, i.e., the stresses and injustices brought about by the capitalist commodification of things in the urban realm and their concomitant value in monetary terms rather than on their usefulness and contribution to the wellbeing of residents. Lefebvre describes the Right to the City as "a superior form of rights: rights to freedom, to individualization in socialization, to habitat and to inhabit. The right to the oeuvre, to participation and appropriation (clearly distinct from the right to property), are implied in the right to the city" (Lefebvre, 1996, p. 174). At its heart, the Right to the City calls for an economic revolution that prioritizes use value over exchange value, a political revolution that calls for the inhabitants as the agents of social change, and a cultural revolution in which living in the city is in itself a praxis of artistic expression (Lefebvre, 1996).

Since Henri Lefebvre wrote Right to the City, the concept has been interpreted and expanded by spatial thinkers including Don Mitchell, Mark Purcell, Peter Marcuse, and Clara Irazábal to conceptualize rights, social struggle, and citizenship claims in a manner that is applicable to the case of non-citizens. For Lefebvre, rights are determined by the inhabitants. Expanding on Lefebvre, Mitchell (2003) asks, who can inhabit the city? Whom should it serve? And by whom should it be governed? Mitchell is primarily concerned with how the "public" is defined and contested. He argues that attacks on public space, through "privatization" and "alienation," are also attacks on the Right to the City. While his work focuses on the homeless, his ideas can also be applied to non-citizens, in the sense that their exclusion from particular spaces through removal is used to constrict who is included in the public and to restrict political participation.

Rather than an individualistic notion of rights based on membership in a nationstate, the Right to the City is divorced from the idea of national citizenship as a prerequisite for political participation. Instead, it is rooted in urban citizenship and the collective use of space. Purcell (2003) questions the usefulness of national scales of citizenship as the basis for rights claims within a global political economy. His concept of the "Right to the Global City" necessarily includes non-citizens in political participation and implies governance by inhabitance. That is, a right earned through everyday life, not necessarily membership in the nation-state. Saskia Sassen (2006) has similarly stated that citizenship and the nation-state are in flux as a result of intensified global economic policies, which require new features of citizenship for emerging postnational and denationalized subjects. Even before this destabilization, U.S. immigration policy had created "impossible subjects" who, according to Mai Ngai (2004), are "a social reality and a 
legal impossibility" (p. 57). According to Ngai, Mexican and Asian immigrants face divergent citizenship trajectories from white Europeans and Canadians. For non-whites, the designation of a racialized or non-racialized identity, undeserving or deserving citizenship, and social exclusion or inclusion, respectively, all hold implications for whether sovereign rights or constitutional rights are exercised on behalf of each group.

For Latinos, the question of ethnicity serves to legitimize discrimination and exclusion, regardless of actual legal status. This became particularly clear following 9/11 when anti-terrorism and immigration enforcement were packaged together by U.S. ICE (Pulido, 2009). In light of this environment, we suggest a broader notion of citizenship rights and formulate conceptual tools that apply rights, and the Right to the City, to the case of non-citizens. The Right to the City better provides what national citizenship does not guarantee for Latino immigrant communities: the right to self-governance regardless of citizenship, the right to political participation beyond the electoral, and the right to be agents of political, economic, and cultural change. By expanding claims to the public, residents have the potential to increase public participation. Within the context of Latin American political activism, for example, Clara Irazábal (2008) has arguedthat "extraordinary events in public spaces have the potential, under certain circumstances, to dramatically expand invented spaces of citizenship" (p. 16). That is, attempts to expand the public through political demonstrations can create new public spaces and citizenship practices that encompass the Right to the City. Irazábal argues that these spaces of citizenship can be distinct from those offered by the nation-state. Taking into account these frameworks, in this article we seek to highlight new forms of citizenship claims and strategies for political participation, as well as efforts to suppress them. The southern California cities of Maywood and Costa Mesa exemplify two such approaches: Maywood's local policies, for the most part, pursue an expansion of rights, while Costa Mesa seeks their contraction.

\section{THE RIGHT TO THE CITY AND LATINO SUBURBS}

A reexamination of the suburbs as both sites of contested ethnoracial politics and the Right to the City as an analytical and mobilizing framework is called for in light of suburbs' increasing numbers of immigrant and minoritized residents. 2 First, this requires considering the unique social, economic, and political formation of suburbs; acknowledging the suburb as a site of transgression; and recognizing the suburb as a port of entry for immigrants. Second, it calls for Lefebvre's notions of rights to be applied broadly. The urban realm is privileged as the most visible stage for both claiming Lefebvre's Right to the City and immigrant rights activism today. An overview of news coverage of the immigrant rights marches, 3 for example, reaffirms this presumption. Occurring throughout cities and suburbs, major cities received the most national media attention, reproducing the bias toward the urban realm as the preferred site for immigrant rights activism. Yet suburban spaces have been critical in shaping local political activism and have helped lay the groundwork for residential, educational, labor, and civil rights activism in the larger Los Angeles metropolis. In Los Angeles, where the suburb and city are intimately tied to one another, adopting a Right to the City framework necessarily requires adopting an investment in a regionally oriented vision. Thus, we build on Lefebvre by focusing on the suburb because it is a key part of the metropolitan geography that is both related to and distinct from the city.

While the suburb is a site of contestation, organizing in the suburbs presents a unique set of challenges. Historically, rights in the suburbs have often been expressed as white homeowners' rights. There is abundant literature on this phenomenon. For example, Lisa McGirr in Suburban Warriors (2002) and Matthew Lassiter in The Silent Majority (2006) discuss how white homeowners were quick to attack outside agitators, threats to individual property rights, and racial integration. Similarly, in her study of a white working-class suburb in Los Angeles, Becky Nicolaides (2002) succinctly summarizes their 
approach when homogeneity was threatened. She states, "they appropriated the language and logic of the civil rights movement in constructing an opposition argument, which hinged partly on the defense of their status as working, taxpaying white citizens. As white homeowners, they were entitled to their own set of rights" (p. 296) - that is, a set of white homeowner rights based on racial segregation and legitimized through a discourse of individualism. Spatially, the historical processes of suburbanization and decentralization reveal spatial forms of racism in which, for instance, whites have been able to move away from older industrial cores and secure relatively cleaner environments (Pulido, 2000). With suburbs as the epitome of the mythical "American Dream"-rooted in the idea of homeownership, the heteronormative family, and white supremacy-suburbs are becoming a symbolic battleground for who has access to rights (legal or natural) in the United States as the Latino and immigrant population increase.

There is a growing literature on people of color in the suburbs (Saito, 1998; Garcia, 2001; Wiese, 2004; Ochoa, 2004; Kruse \& Sugrue, 2006).While Latinos have always settled in suburbs to some degree, there has been a significant intensification occurring as a result of deindustrialization and rising housing costs in the last three decades. This shift has derived from both private land development and the relocation of industry to the suburbs. Within the Southern California Association of Governments (SCAG) region, encompassing the Los Angeles, Orange, San Bernardino, Riverside, Ventura and Imperial Counties, Latino migration has contributed to a net increase in Latino residents from $10 \%$ to $40 \%$ between 1960 and 2000. Fifteen percent of the nation's total immigrant population and 25\% of the nation's unauthorized immigrants live within the SCAG region alone (Chang, 2007). According to a special report by the U.S. Census Bureau on Migration and Geographic Mobility in Metropolitan and Nonmetropolitan America, in 2000 over 324,000 "movers from abroad" migrated to central cities, while over 375,000 migrated to suburbs, in the Los Angeles-Orange-Riverside Metropolitan Area (Schachter, Franklin, \& Perry, 2003).4 That is, more immigrants are migrating to suburbs than to central cities in southern California. Immigrants' new locational choices and the impact of these new settlement patterns on non-traditional receiving communities are being experienced in other metropolitan areas as well, including Phoenix, Atlanta, and Sacramento (Singer, Hardwick, \& Brettell, 2008). The large concentration of the nation's immigrant population, the intensification in immigrant suburbanization, and the growth of similar cases throughout the nation make the Los Angeles region a particularly significant site to explore the resulting tension between white homeowners' rights and broader rights claims based on inhabitance.

With suburbs becoming the new immigrant gateway communities (Singer, Hardwick, \& Brettell, 2008; Singer, 2004), the exploration of rights in suburbs is crucial to innovative understandings of citizenship, political access, and self-governance. Yet, people of color in suburbs are often treated as apolitical, and suburban struggles are often assumed to be conservative and, as a result, are undertheorized as sites of liberatory struggle. Our case studies illustrate an alternative reading of suburbs, not only as "ethnoburbs" with a high concentration of immigrant and ethnic workers that comprise an "urban mosaic" which promotes economic mobility for residents through social and business networks in a globalized economy (Li, 2006), but also as sites where new identities are formed, racial lines are challenged, and community formation is contested. At the core of the resulting battles, residents are debating who has the right to determine who can and cannot live in the suburb and under what conditions. It is precisely residents' divergent claims to these rights that ignite tension between citizens and non-citizens. The Right to the Suburb allows a way to approach these diverse struggles, while accounting for the unique openings for action allowed in the suburb as a historical, political, and ideological construct. At the same time, claims by immigrants in suburbs offer an exciting way to broaden the application of the Right to the City.

By examining the events in Costa Mesa and Maywood, the following sections seek to understand the response of the City Councils, community organizations, and residents 
to the intensification of Latino migration into these suburbs (Figure 2). We examined City Council minutes, media accounts, demographic data, and archival materials from Costa Mesa and Maywood regarding key events and proposals related to immigrant rights. We asked, how have Costa Mesa and Maywood responded to immigration debates? How have their political and cultural histories affected who is able to live and move freely through the city? And what factors determine how rights are minimized or maximized? Furthermore, how have residents shaped these responses?

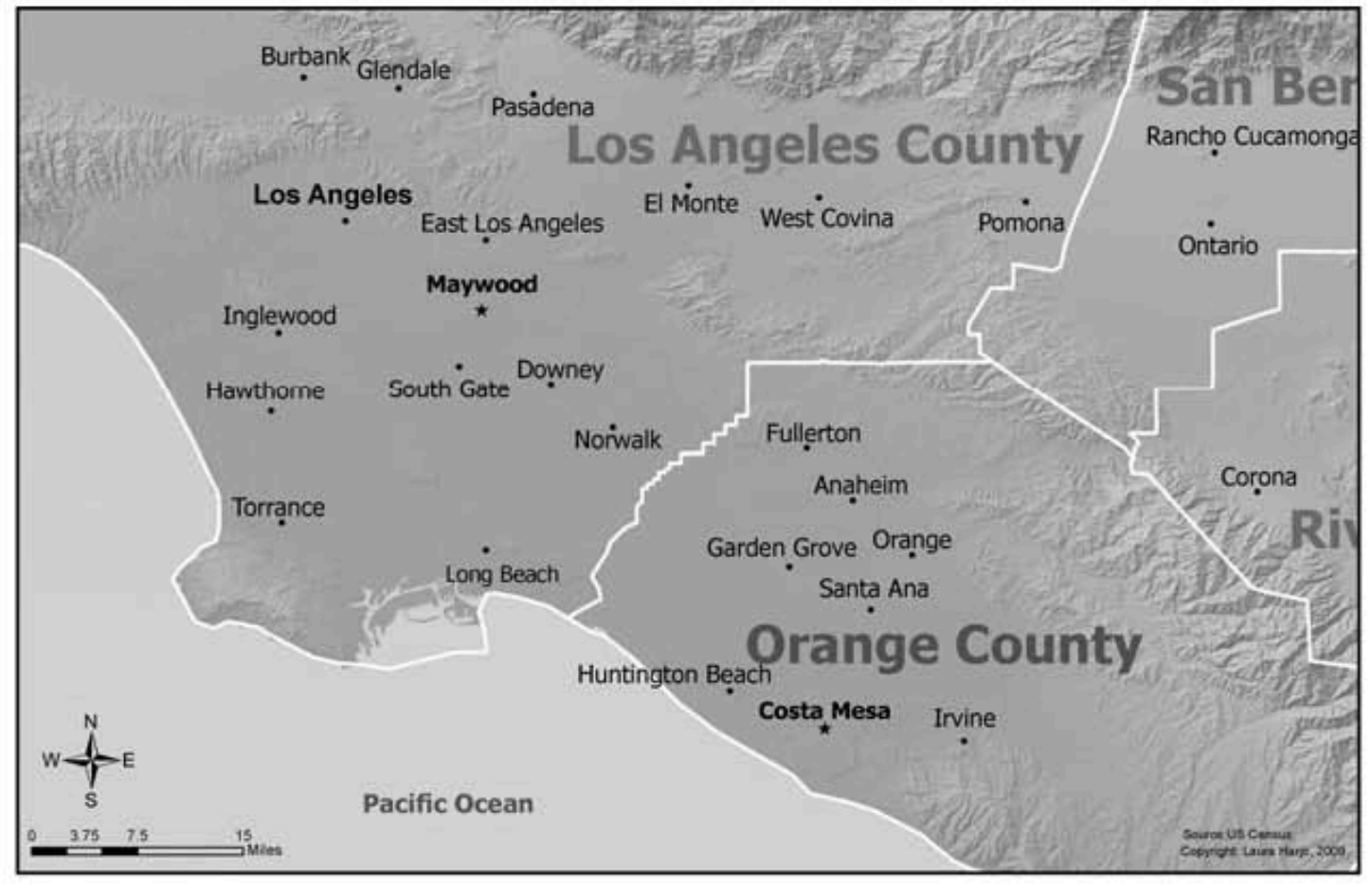

FIGURE 2

Map of Maywood, Costa Mesa, and Surrounding Areas. Courtesy of Laura Harjo, 2009

\section{COSTA MESA}

Best known for upscale shopping, televangelism, and stucco-lined streets, behind the veneer of effortless suburban homogeneity made popular in the TV series The O.C. and the Real Housewives of Orange County lie some of the most controversial and restrictive approaches to suburban immigration in the nation. Over the past 20 years, Costa Mesa's City Council has passed numerous policies targeting Latino immigrants, from banning soccer in public parks to closing a job center serving day laborers (Caspa, 2008). These attacks were overshadowed when, in one of the most controversial moves made by a municipal government, Costa Mesa's Mayor Allan Mansoor proposed in 2005 a partnership with ICE that would allow local law enforcement agents to identify, process, and detain immigrants. Attempts to reclaim the Right to the Suburb by immigrant advocates through attending City Council meetings and demonstrations proved unsuccessful when countered by conservative councilmembers, influential antiimmigrant organizations, and federal policies extending immigration enforcement to local governments. Claiming to only target immigrants with "aggravated felonies and criminal street gang activity," in its first year of operation over 3,000 people were identified for deportation by a partnership with II Right to the Suburb? Rethinking Lefebvre and Activism 191 ICE (City of Costa Mesa, 2005; Santana \& Saavedra, 2007a). Costa Mesa became the program's national leader in deportations and a model for other suburban governments anxious to restrict the growing number of Latino residents. Through a discourse of minimum rights and facilitated by federal policies, Costa Mesa suppressed 
citizenship claims, restricted political participation, and curtailed the Right to the Suburb for Latino residents and denied it to unauthorized immigrants.

\section{History}

Costa Mesa's response to the rise in its immigrant population can at least partially be traced to its political and cultural history. Costa Mesa, described by bestselling satirical author Gustavo Arellano as "condemned to be known as the place where a Mexicanbashing mayor came into office" (2008, p. 146), has a history rooted in exclusion, militarism, and conservatism. Such history made it a fertile ground for the surge of antiimmigrant activism experienced in the 2000s. Located 37 miles southeast of Los Angeles, in central Orange County, Costa Mesa boomed following World War II. Historian Lisa McGirr (2002) has argued that through federal funds granted for defense, Orange County was transformed into a regional power. The construction of the Santa Ana Army Air Base in 1941 brought in soldiers from across the U.S. Many veterans decided to settle in Orange County, and particularly in Costa Mesa, when the Air Base closed at the end of the War in 1946 (Miller, 1981). Despite its closing, many newly located manufacturers were intimately tied to military markets, such as fiberglass, advanced technical ceramic products, and cryogenic pumps. The economic restructuring of industries in inner suburbs such as Maywood, an explosion in suburban tract housing, and white flight from central L.A. following theWatts 1965 rebellion (Pulido, 2000) all contributed to a white population boom in the historically small town. In the 30-year period between 1940 and 1970, Costa Mesa grew from 4,000 residents to 72,000 (Barr, 1981). Even today, the tax income generated from the concentration of manufacturing and high-end retail in the city helps subsidize the affluence of Costa Mesa residents, where the median household income is above $\$ 75,000$ (City of Costa Mesa Planning Division, 2007). Comparatively, the median household income in all of California was under $\$ 60,000$ in 2007 (U.S. Census Bureau, 2005-2007). The conservative climate grew in the 1960s during which time, McGirr (2002) argues, there was a growing movement of "suburban warriors" that played a critical role in galvanizing and mobilizing conservatives at the grassroots level in Orange County. The combination of residents with links to the military, a war-based economy, suburban tract housing, and a politically active constituency made Costa Mesa a popular site for conservative homeowners.

\section{The Changing Color of Costa Mesa}

While the political-economy and history ofCosta Mesa made it a quintessential white suburb for several decades in the twentieth century, it has recently experienced unprecedented growth in its Latino population (Caspa, 2008). From 1970 to 2000, the immigrant population in Orange County grew from $6 \%$ to $30 \%$, with the majority of migrants arriving in Orange County between 1990 and 2000 (Center for Demographic Research, 2003).5 While Costa Mesa remains predominantly white, the population is projected to be predominantly Latino within the next 30 years. According to Chicano activist Nativo Lopez, "Residents here in Costa Mesa see a changing complexion, a racial complexion, and they feel out of place" (Lagorio, 2006). The Costa Mesa City Council has responded to the increasing number of Latinos through recent anti-Latino policies, affecting both immigrants and non-immigrant Latinos, including eliminating the Human Relations Committee, prohibiting adult soccer in public parks, reducing federal funding to organizations that serve minority groups, and closing the Costa Mesa day labor center, an important resource for Latino immigrants seeking employment (Caspa, 2008). In Costa Mesa, a white conservative majority 


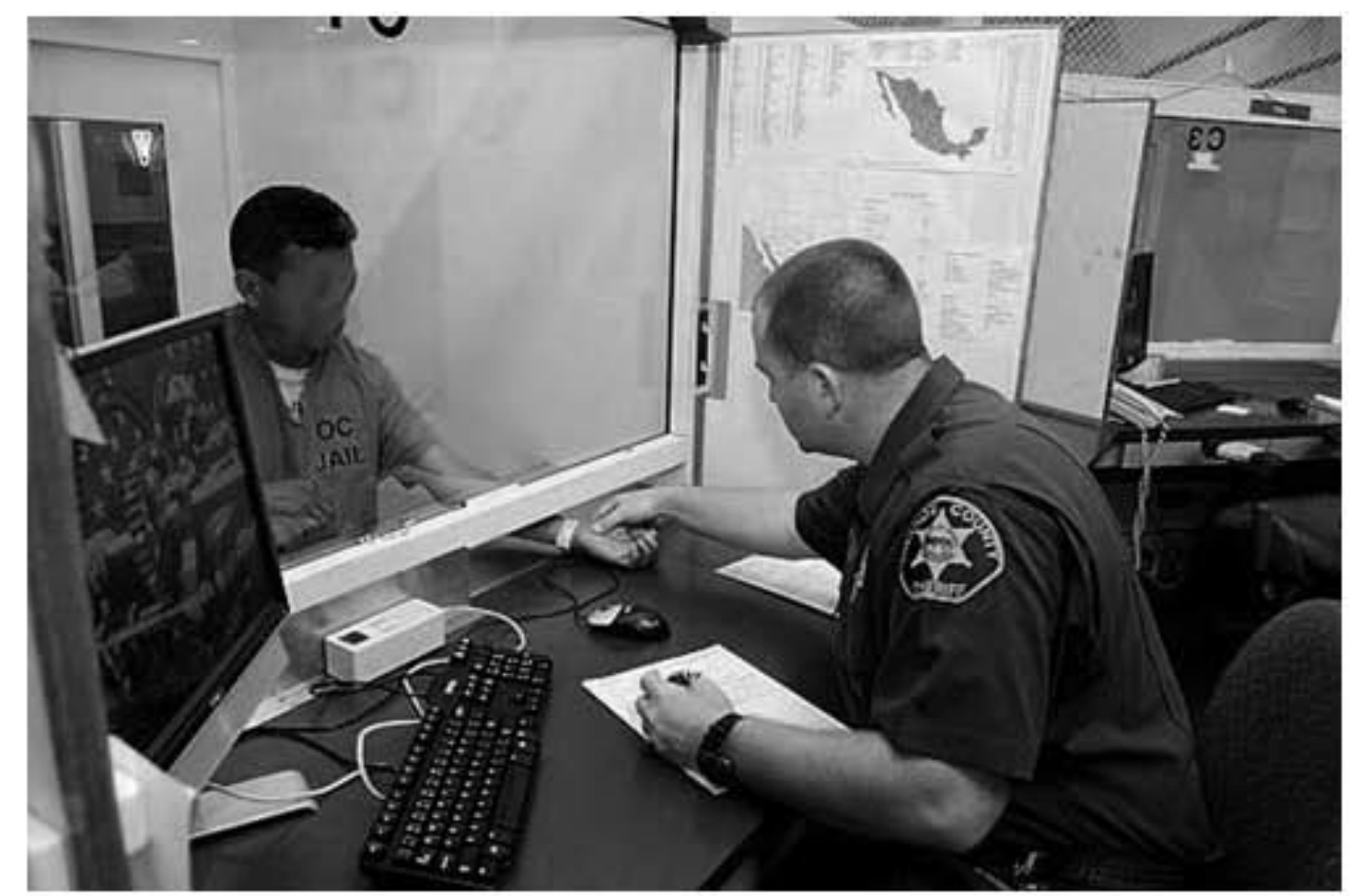

FIGURE 3

Detainees Being Screened by Orange County Sheriff's Department for Immigration Status. From Santana and Saavedra (2007b). Felons Found in Police Immigration Screening. Orange County Register. Available at http://www.ocregister.com/photos/costa-mesa-crime1942532immigrationpolice/pid1942533

such as that described by Nicolaides (2002), has minimized immigrant rights to retain a certain ideal of the suburb rooted in white homeownership. Costa Mesa's politicaleconomic history compounded with the increasing suburbanization of Latinos in a new scenario laid a strong foundation for activists interested in maintaining their privilege at the cost of minimizing the rights of immigrants and those perceived as immigrants.

\section{Minimizing Rights: Violating Collective Rights, Inhabitance, and Public Space}

In 2006, Coyotl Tezcalipoca (Benito Acosta in his non-indigenous name) was forcefully removed from a City Council meeting by the Costa Mesa police department at the order of the Mayor during the public comment section. The Tonantzin Collective, an immigrant rights group in Costa Mesa, began singing "We Shall Overcome"6 as their representative was removed from the City Council Chambers for speaking against the council's decision to enforce federal immigration policy locally (Figure 3). They were answered by a chorus of opponents singing "God Bless America," ironically, a song written by an immigrant.7 Immigration enforcement is a federal responsibility, but through the ICE Agreements of Cooperation in Communities to Enhance Safety and Security (ACCESS) program umbrella, ICE is able to partner with state and local law enforcement to provide the training and subsequent authorization to identify, process, and detain immigration offenders they encounter through programs such as 287 (g) and the Criminal Alien Program, also known as CAP (U.S. ICE, 2009b). Whereas Orange County's Sheriff's Department had earlier entered a formal 287 (g) agreement with ICE, Costa Mesa's police department began enforcing federal immigration policy through CAP residents a conservative City Council majority.8 While the 287 (g) program crossdesignated Orange County officers to enforce immigration law, through CAP the Costa 
Mesa city jail assigned ICE officers to identify and hold deportable legal permanent residents, visa holders, and unauthorized immigrants on an immigration detainer that ensured their removal to ICE custody upon their release (U.S ICE, 2007). Programs such as these clearly violated immigrants' Right to the Suburb by targeting their inhabitance.

When a partnership with ICE was first discussed in Costa Mesa, the proposal evoked a strong public response. Those in opposition feared it would create ethnic conflict, increase public liability, and foster fear amongst unauthorized workers. Many were concerned it would undermine the relationship between the police and community, lead to racial profiling, and violate the equal protection of all citizens. Others felt it was outside the realm of the local, stating that it diverted the attention of officers to an issue that should be addressed at the federal level and that it turned police officers into immigration agents instead of peace officers. Chief of Police John Hensley, it was later revealed, even privately advised City Council members against enforcing immigration laws out of concern for "community-oriented policing" and the allocation of department resources it required. When asked about his concerns regarding cross-designation of police officers for immigration enforcement in a disposition with the ACLU, Hensley stated "Particularly with Costa Mesa, it was the [Latino] community on the Westside [that worried me]. My belief and opinion at that time was that taking on this program would harm that relationship we worked so hard to create" (Serna, 2008). Those in favor of the motion adhered to a concept of citizenship staunchly rooted in the nation-state, arguing that a person violating national immigration law had no right to be in the city of Costa Mesa. They drew on color-blind anti-terrorism rhetoric that emphasized the intent of the Memorandum of Agreement (MOA) to screen dangerous criminals, arguing it was a public safety issue with reasonable limits. According to City Council minutes, Councilmember Gary Monahan stated "it would target enforcement efforts against those who are involved in aggravated felonies and criminal street gang activity" (City of Costa Mesa, 2005). After the more liberal council member Linda Dixon suggested a study session with community leaders such as the ACLU and LULAC to explore the implications of the contract, she was quickly outvoted by Mayor Allan Manson, Mayor Pro Tem Eric Bever and Councilmember Gary Monahan who "did not feel it necessary to include it in the motion" (City of Costa Mesa, 2005). This was more than an issue of pro- and anti-immigrant binaries. Some residents felt immigrants should be allowed to live in Costa Mesa, regardless of documentation, under certain conditions. The delineation between deserving and undeserving residents was based on an approved set of behaviors-such as temperance, adherence to U.S. laws, industriousness, and a desire to assimilate-which demarcated the boundaries of social exclusion and inclusion. In their own way, residents were disputing who has the Right to the Suburb.

In 2006, newcomer Wendy Leece and incumbent Mansoor were elected to the City Council by running on a joint platform that focused on "improving" Costa Mesa through increasing immigration enforcement (Linder, 2006).Wendy Leece's campaign echoed the sentiment of Mayor Mansoor. Her campaign website read, "I am concerned three illegal sex offenders were recently found in Costa Mesa and that not all illegal aliens are deported after serving their jail time. I support Mayor Mansoor's proposal to deport major felons and am the only candidate endorsed by the Mayor" (Leece, 2006). In a blog following his election, Mayor Mansoor reflected on his campaign slogan "Improving Costa Mesa." He described his work as part of an "Improver Movement" of residents who suffered from "a general feeling of a low quality of life" and wanted "things fixed" (Mansoor, 2006). For Mansoor, "improving" Costa Mesa meant having "something done about immigration." Perhaps responding to rising tensions between immigrant rights advocates and nativists in suburbs such as Maywood, in a separate blog on illegal immigration he stated, "The American community is standing up and asking its elected officials to uphold the law. We are doing our part in Costa Mesa" (Mansoor, 2007). Another blog entry illustrates his definition of American identity. He stated, "Those that come here should also learn English and a desire to assimilate." He echoes this sentiment in another blog, "American without a 
hyphen" (Mansoor, 2006). Mansoor demonstrates that coming from a family of immigrants (according to 194 II JOURNAL OF URBAN AFFAIRS II Vol. 33/No. 2/2011 the blog entry, his father was born in Egypt and his mother in a province of Finland) does not necessarily ensure one will have a more progressive stand on immigration policy. The election of Wendy Leece and Allan Mansoor over more liberal candidates suggests electoral activism can be used to hinder expanded conceptions of citizenship such as the Right to the Suburb. As stated by Dan HoSang, "California's system of direct democracy has proved to be a reliable bulwark against many leading civil rights and anti-discrimination issues" (HoSang, 2007, p. xi). Indeed, this was the case in Costa Mesa.

Within a month of the election, Costa Mesa entered the partnership with ICE despite strong opposition from community organizations and sectors of the public. The agreement gave Costa Mesa's police officers the training, human resources, and legitimation of the nation-state to help them inhibit immigrants' ability to go about everyday acts while in Costa Mesa. This is part of a larger trend in which the federal government is devolving responsibility for immigration-related policies to local governments (Varsanyi, 2008). From Oklahoma to New Hampshire, ICE access cases have arisen in sites far removed from the U.S. borderlands. For instance, there are currently at least 950 ICE-trained officers and 66 active local governments with 287 (g) MOAs (U.S. Immigration and Customs Enforcement [ICE], 2009a). Through stretching the border and its enforcement to new sites, some local governments are contracting rather than expanding spaces of citizenship and belonging for residents. Whereas other places with CAP MOAs had part-time agents, an ICE officer worked at the Costa Mesa city jail on a fulltime basis, thus consuming a great share of federal resources more than a hundred miles from the border and without any apparent national security reasons. This investment allowed Costa Mesa's law enforcement to deport unauthorized residents, legal permanent residents, and visa-holding immigrants at an unprecedented rate (U.S. ICE, 2007). Arrests soared. ICE began training sheriff deputies to conduct checks on $100 \%$ of inmates, whether or not they received a conviction, thus violating the City Council's earlier assurance at council meetings that only dangerous criminals would be screened. In its first week of operation, Costa Mesa, now armed with the authority of federal law enforcement, netted 175 immigrants for screening (Robinson, 2007). By the end of the first year, over 3,000 people were identified for deportation (Santana \& Saavedra, 2007a). Several of these cases were thrown out by the District Attorney's Office, because the majority were brought in for minor convictions, including jaywalking, driving without a license, and possession of illegal substances (Santana \& Saavedra, 2007b). The MOA effectively legitimized the systematic identification, criminalization, and of immigrants living and passing through Costa Mesa. Through enforcing a framework of rights based on membership in the nation-state, and hence criminalizing the inhabitance of unauthorized immigrants, Costa Mesa embraced a minimal discourse of rights that challenged the Right to the Suburb by denying immigrants political access, public space, and collective rights. At the same time, the MOA instilled fear in all Latinos through racial profiling and hurt the relationship between the Costa Mesa police department and the predominantly Latino Westside community (Serna, 2008).

\section{Contestation}

Costa Mesa's local approach to immigration enforcement was facilitated by regional networks of anti-immigrant activists and national discourses on immigration policy rooted in exclusion and militarization. Nativist groups, including Save Our State (SOS) and the Minutemen, drew from resources and residents from across Southern California who came to express their support of the MOA at City Council meetings. For those who did not participate in person, online blogs provided updates on the case with articles, photos, and opportunities for public comment. The Minuteman Project reportedly even held a fundraiser for Mayor Mansoor in support of his immigration policy. II Right to 
the Suburb? Rethinking Lefebvre and Immigrant Activism II 195 Justin Akers Chacón and Mike Davis (2006) explain that, behind the Minutemen's color-blind rhetoric that focuses on the illegality of immigrants, rather than their ethnorace lies a racially infused "propaganda of fear." Residents from throughout the county shared their support of the MOA in public comments to the Daily Pilot, a local newspaper. In response to an article, "ICE Traces Illegal Immigrants," a striking, though not exceptional, comment stated "Round them all up. In Costa Mesa all you have to do is drive on the West Side of Costa Mesa and you will find hundreds of illegals [sic] driving without a license or insurance. Costa Mesa is becoming a Costa Mexico." Similar remarks state, "Get them ICE," "Keep up the great street 'sweeping'," and "I'm glad ICE is doing a fine job cleaning up our fine city," amongst others (Robinson, 2007). While Costa Mesa's police officers have exercised extreme policing of immigrants, their approach to enforcement has been met by its share of opponents. Some of the most vocal critics of the new policies include the Tonantzin Collective and the Citizens for Constitutional Rights, two local immigration rights groups. Immigrant activists first appealed to the City Council through public comment at City Hall meetings and through an economic boycott. For instance, before Coyotl Tezcalipoca was arrested at a Costa Mesa council meeting, he delivered a heart-felt speech on behalf of the Tonantzin Collective demanding a reversal of the ICE agreement (City of Costa Mesa, 2006a). The Collective equated the efforts of the City Council and ICE towards Latinos to efforts to remove them from Costa Mesa. Tezcalipoca stated, "You Allan Mansoor and Eric Bever this is a task for both of you guys, three of you guys [third council member indicated is unclear], to gentrify Mexicans, Central Americans, and South Americans out of Costa Mesa. We know that you guys want to change the demographics of Costa Mesa. We know your plot and you guys make sure, all of you, make sure that we are going to be here and fight this to the end" (The Watchdog, 2008). During earlier comments, Minutemen leader Jim Gilchrist asked his supporters to stand. When Tezcalipoca asked his supporters to do the same at the same meeting, however, he was arrested for disrupting an assembly and obstructing an arresting officer (Martinez, 2006).

When the attempts of immigrants and their advocates to reclaim the Right to the Suburb were met with constriction of their political participation and their claims for selfgovernance, they turned to lawsuits and public demonstrations. Amongst these efforts, the Tonantzin Collective organized a protest at City Council chambers, and Citizens for Constitutional Rights organized a boycott. In April 2006 over a thousand people from Costa Mesa and nearby suburbs marched to the City Hall to protest its anti-immigrant policies and as a response to the federal legislative proposal HR 4437 (Caspa, 2008; Archibold, 2006).9 By staging protests at the symbolic heart local anti-immigrant policy, the demonstrations ruptured the authority of the City Council to speak for the people and revealed residents' unrest and their capacity to reclaim decision making authority, albeit temporarily. It is important to note these acts preceded the nation-wide demonstrations protesting HR 4437. Through later joining with regional movements in Downtown Los Angeles, immigrant advocates unified in a common call for expanded rights and a new framework for citizenship.

Mansoor announced his intent to run for the 2010 state legislature, and in November 2009 he was elected. He has promised to continue his commitment to broad enforcement of U.S. immigration policies (Blank, 2009). Concurrently, Coyotl Tezcalipoca partnered with the American Civil Liberties Union to file civil charges against the City of Costa Mesa for violating his freedom of space when he was forcefully removed from the 2006 City Council meeting (Serna, 2008). In December 2009, a federal jury found that his first amendment rights were not violated, a frightening precedent for free speech advocates (Pak, 2009).

\section{MAYWOOD}


In Costa Mesa, rising immigration has been met by a discourse of minimal rights exercised through mass displacement, limiting political participation, and restricting immigrants' claims to the suburb. A few miles away, in neighboring Los Angeles County, Maywood's approach to immigration has been transformed into a discourse of maximum rights based on inhabitance. When traffic checkpoints effectively amounted to a "municipal tax" on immigrants, residents of Maywood began to mobilize. They made important strides toward self-governance, including defeating the traffic checkpoints, increasing control over the police through a citizens' commission, and successfully campaigning to elect immigrant advocates to public office. These efforts gained national attention when, in a controversial move, Maywood openly refused to enforce federal immigration law in the wake of HR 4437. Self-appointed a "Sanctuary City," Maywood simultaneously became the target of anti-immigrant activism and a rallying cry for those seeking to extend new understandings of citizenship.

\section{History}

Like Costa Mesa, Maywood's response to immigrant rights can at least partially be traced to its political, economic, and cultural history. Located close to the city of Los Angeles, Maywood was the heart of the machinery-metallurgical industries in the Los Angeles region when it was founded in 1924. The availability of factory work, coupled with an abundance of half-acre garden home sites complete with racial deed restrictions, led to a community of white industrial workers (Ahrens \& Urbina, 2005). Racial residential restrictions were prevalent and openly advertised in Chamber of Commerce publications. One such advertisement stated, "No property, prior to May 1945, can be sold, conveyed, rented or leased to any person not of the caucasian [sic] or white race" (City of Maywood, 1998). This "commonsense" approach to home ownership persisted well beyond the 1950s. For the neighboring city of South Gate, historian Becky Nicolaides (2002) has argued that homeowner rights and white rights were often synonymous. She states, "South Gate residents waged the most forceful arguments against integration by emphasizing the rights and well-being of whites" (p. 301). By the 1980s, however, assembly plants began relocating, businesses closed, and the white majority began moving out of deindustrializing Maywood in Los Angeles County and into neighboring suburbs in Orange County. Whites followed higher-paying jobs in the burgeoning manufacturing sector, while the demand for low-wage labor in Southeast Los Angeles' manufacturing district contributed to the Latinization of its inner suburbs. Despite the privilege Maywood had previously enjoyed as an industrial-residential hub, by 2000 per capita income had fallen to well below that of suburbs in Orange County. Today, manufacturing remains the leading industry employing residents $(22 \%)$, but many are employed in low-paying production, transportation, and material-moving occupations $(42 \%)$ (U.S. Census Bureau, 2000). Maywood's downward mobility is similar to other manufacturing suburbs in Southern California, whose residents suffer from compressed wages. The combination of newly vacated housing, proximity to factory work, and the end of racially restrictive housing covenants made Maywood a popular site for new immigrants.

\section{The Latino Majority in Maywood}

While Maywood was a white residential-industrial hub throughout the 1900s, by the end of the century it had experienced a major dramatic demographic shift. Between 1970 and 2000, Maywood shifted from 97\% White to 96\% Hispanic ("Population profile," 1971; U.S. Census Bureau, 2000). The demographic changes were reflected in Latinooriented publicly sponsored events, printing public documents in Spanish, and electing an all-Latino City Council. Of those who identified as Hispanic on the U.S. Census, almost half identified as non-citizens (42\%). It is difficult to assess how many residents are without 
U.S. authorization. According to a study by the International City/County Management Association (ICMA), about $40 \%$ of immigrants nationwide are believed to be unauthorized, which was confirmed by a local council member who estimated that a third to half of the total population in the city of Maywood is unauthorized (ICMA, 2008; Traux, 2006). In Maywood, where Spanish speakers outnumber English speakers, anti-immigrant policies stemmed from tensions between the police department, intra-ethnic conflict, and discriminatory state and federal policies. However, policies limiting the rights of nonU.S. citizens would be confronted by a movement for maximizing immigrant rights and expanding their Right to the Suburb.

\section{Maximizing Rights: Embracing Collective Rights, Inhabitance, and Public Space}

In 2003, Flor Cervantes and her children were left stranded on the sidewalk carrying whatever possessions they could hold as they watched a tow truck drag their car to the impound lot by order of the Maywood traffic division. Unable to afford the charges for a mandatory 30-day hold, which ranged from $\$ 1,000$ to $\$ 1,600$, Cervantes's car was sold at an auction by Maywood's Club Tow (Del Olmo, 2003a). At checkpoints, residents driving down Maywood's main thoroughfare found themselves trapped by blue and red lights as they waited in line for police officers checking sobriety, driver's licenses, and proof of insurance. While the police department claimed the purpose of the checkpoints was to catch intoxicated drivers, residents argued they were intended to criminalize and profit from immigrants.

As a consequence of 1993 Senate Bill 976, applicants without proof of lawful presence in the United States are prohibited from receiving a California driver's license or State ID card. When SB 976was coupled with a 1987 California Supreme Court decision approving traffic checkpoints to identify drunk drivers, state-sanctioned sobriety checkpoints essentially functioned as local immigrant checkpoints by identifying, criminalizing, and taxing unlicensed Latino immigrants. In 2002, for instance, 1,800 cars were impounded as a result of traffic checkpoints (Del Olmo, 2003a). When compared to the seven drivers that were cited for drunk driving, it becomes clear that checkpoints targeted immigrants and not intoxicated drivers. Maywood imposing traffic checkpoints after a police officer was killed in a fatal crash with an unlicensed driver, but many believe they remained because of profits gained by the city from towing and impound fees, which are estimated to have been approximately $\$ 250,000$ a year (Del Olmo, 2003b; Raouf, 1999). Anyone stopped at a traffic checkpoint without a license, e.g., all unauthorized immigrants, had their car impounded, held a mandatory 30 -days at a $\$ 30$-aday fine, received a citation, and were required to pay a release fee. According to Nativo Lopez, "It amounts to a municipal tax on immigrants" (Anderson, 2007).10

The traffic stops became a highly contested issue at City Council meetings, which generated questions about state policies penalizing unauthorized residents and revealed other claims of police abuse including beatings, sexual assault, and racial profiling (Lait \& Glover, 2007). These injustices galvanized many Maywood residents. Residents stated that family members without papers avoided visiting them from other cities because they feared their cars would be impounded, teachers reported that the traffic stops were affecting children who were increasingly afraid of the police and whose parents were afraid of driving them to school, and drivers argued that the police were using racial profiling, thus violating the equal treatment of residents (City of Maywood, 2003b).Whereas in Costa Mesa policies were aimed at immigrants and often affected all Latinos, traffic checkpoints more explicitly, though not exclusively, targeted unauthorized immigrants. In Maywood, an all-Latino City Council did not necessarily translate into immigrant-sensitive policy. Instead, it reflected a long-standing tension between native-born and non-native access to rights (Gutierrez, 1995; Ochoa, 2004; Garcia-Bedolla, 2005; Pulido, 2007). social dynamics in Maywood highlight the extent to which some native-born Latinos have selectively disassociated from immigrants due to 
fear of stigma and bought in an anti-immigrant sentiment and a law and order mentality that justifies the exclusion of immigrants based on legal status (Garcia-Bedolla, 2005; Pulido, 2007).

Saint Rose of Lima, a local church played a central role as a political social space for immigrant advocates. After months of public dissent at City Council meetings, the council accepted an invitation from Father David Velasquez to attend a meeting with residents at the church to discuss the effect of checkpoints on locals (City of Maywood, 2003a). This venue shift weakened the hierarchical structure of the council meetings. While never absolving the power structure completely, council members and residents met on closer terms before the priest in a shared social space where they often attend services together. As a result of the meeting, City Council members agreed to waive the 30-day hold for first-time offenders and changed the traffic checkpoints from the early evening, when people were driving home from school and work, to after $10 \mathrm{PM}$ when they were more likely to stop drunk drivers. This was a victory for organizers. Saint Rose of Lima, Comité Pro Uno, a community-based non-profit in Maywood, and One Los AngelesIndustrial Areas Foundation (LA-IAF) led the movement against the traffic stops and were at the forefront of a growing movement for immigrant rights in Southeast Los Angeles (Del Olmo, 2003b). Marcos Hernandez of the LA Metro Project/One LA-IAF, a nonpartisan organizing network that seeks to empower residents to participate in local government, stated, "We have been working with these guys for three months to be able to show them that we have the power to organize" (Cardenas, 2003). Arguing that the police exist to serve the public, Maywood residents and their allies successfully fought for public overview of the police department by a commission composed of members from immigrant rights organizations (City of Maywood, 2006d). Mobilizing to fight the traffic check points gave Maywood activists the networks, training, and experience to help them defeat anti-immigrant policies and fight for the right to inhabit Maywood.

As they continued to gain momentum, activists grew frustrated with City Council members whom they felt did not respect residents. For instance, residents accused members of the council of being corrupt (City of Maywood, 2005b), using "overpowering methods" (City of Maywood, 2005a), and failing to fulfill the responsibilities of their office (City of Maywood, 2005a), and suggested that no one had listened to Latino immigrants (City of Maywood, 2006b). As a result, residents organized to maximize their decisionmaking authority by seeking to create a new council through voter drives centered at the Saint Rose of Lima Church. In partnership with Los Angeles County-based and nationally organized One LA-IAF, over 100 congregants agreed to recruit 10 registered voters each to discuss their political campaign. Through incorporating Maywood's small size into a grassroots activism model based at the church, their organizing efforts were highly successful. Voter turnout doubled from the previous year with nearly all registered voters casting a ballot (Traux, 2006; Radford 2006). In November 2005, Sergio Calderón and Felipe Aguirre, two immigrant advocates, were elected to the City Council. Representatives from immigrant rights organizations including Padres Unidos de Maywood, League of United Latin American Citizens (LULAC), One LA-IAF, and Union of Neighbors came to greet the new City Council members at their inaugural meeting. The public celebrated what they considered a "historic change" (City of Maywood, 2005a). But it is not the electoral victory that makes this approach consistent with Right to the City. Rather than embracing national citizenship, voter registration and citizenship application workshops were part of a multi-pronged strategy whose overall goal was to increase local political participation and council accountability to all residents, regardless of citizenship status. The discourse adopted by residents was not one of assimilation. Ultimately, they were fighting for the right to be there, to use the suburb freely, and to avoid persecution at work. Their larger goal was to ensure residents could directly affect public policy in the neighborhood, not necessarily to attain U.S. citizenship. Nevertheless, their opposition was intimately tied to issues of national exclusion and federal immigration laws that operate at the local level. 
The election of Calderón and Aguirre to the council, which already included immigrant supporter councilmember Thomas Martin, gave the City Council a liberal majority, leading to the passing of a number of pro-immigrant policies, including declaring a resolution to restore the Dream Act,11 calling for a moratorium on impounding cars for equipment violations, and requiring the early release of vehicles impounded from unlicensed drivers ineligible for a license. In one meeting, Councilmember Felipe Aguirre specifically asked that the city change state law with regard to more lenient impound policy (City of Maywood, 2006b). By mid-December, the new council reviewed the 30-day holding for impounds and released them to unauthorized immigrants, reducing impounds from 206 cars in December to only 15 in January, a huge victory for organizers (City of Maywood, 2005b, 2006a). Maywood inspired action in other suburbs with traffic checkpoints. For example, on the other side of Los Angeles County, in the city of Pomona, residents and students have protested traffic checkpoints through rallies, attending City Council meetings, and discussing a class action lawsuit (Carpio, personal observation, March 28, 2009; Pomona Checkpoints, 2009). It is a demand for a broader notion of rights, such as those described by Lefebvre, to attain the right to move freely within the city and the right to determine its policies based on their residency in the suburb, regardless of one's citizenship status.

Maywood was a fertile ground to make further claims for rights when in December 2005 the proposed Clear Act amendments to HR 4437 threatened to switch federal citizenship violations from civil to criminal offenses for immigrants and those who helped them, and to rescale the enforcement of immigration laws to state and local law enforcement agencies (GovTrack.us. HR 4437-109th Congress, 2005). In response, on January 24, 2006, Maywood's City Council passed Resolution 5225 opposing the Clear Act and the Sensenbrenner-King Immigration Restriction Bill HR4437.12 The Resolution argued that the bill burdened police with enforcement of technical civil immigration status, diverting them from priority tasks of public safety; discouraged immigrants from coming forward to report crimes and suspicious activity making streets less safe; was an unfunded and unsafe mandate imposed on the police department; and violated the police department policy "that officers shall not consider ancestry, race, ethnicity, national origin. .. as sole basis for establishing reasonable suspicion, probable cause, or a basis for requesting consent and search," and "as currently written, is unfairly punitive, and is not reasonably designed to combat terrorism or enhance the security of the United States of America" (City of Maywood, 2006b). Because Maywood was already equipped with a politicized set of residents, activist networks, and a radical City Council opposed to state laws contrary to local interests, it was able to respond to HR 4437 with a resolute defense of immigrants' rights (Figure 4).

By openly opposing the bill, Maywood was soon labeled a Sanctuary City (Cuevas, 2006). Maywood, in addition to other cities, including Berkeley, San Francisco, New Haven, Albuquerque, Seattle, and Durham to name a few, is part of this national movement (ICMA, 2008). The Church of Saint Rose of Lima was at the center of this struggle, part of larger trend in which immigrants adopt religious spaces and transform them into meaningful spiritual, cultural, and political places (Irazábal \& Dyrness, 2010; Kotin, Dyrness, \& Irazábal, forthcoming). Similar to the church-based Sanctuary Movement, in which the church serves as a safe haven from persecution, Sanctuary is a symbolic status taken on by cities who do not allocate funds to enforce federal immigration law, but on the contrary make concerted efforts to make access to education, health, public space, police, and other resources safe for unauthorized immigrants. As described by a survey of local governments' reactions to immigration concerns, "Although the specific provisions of each sanctuary ordinance vary, the common denominators are that they focus on 


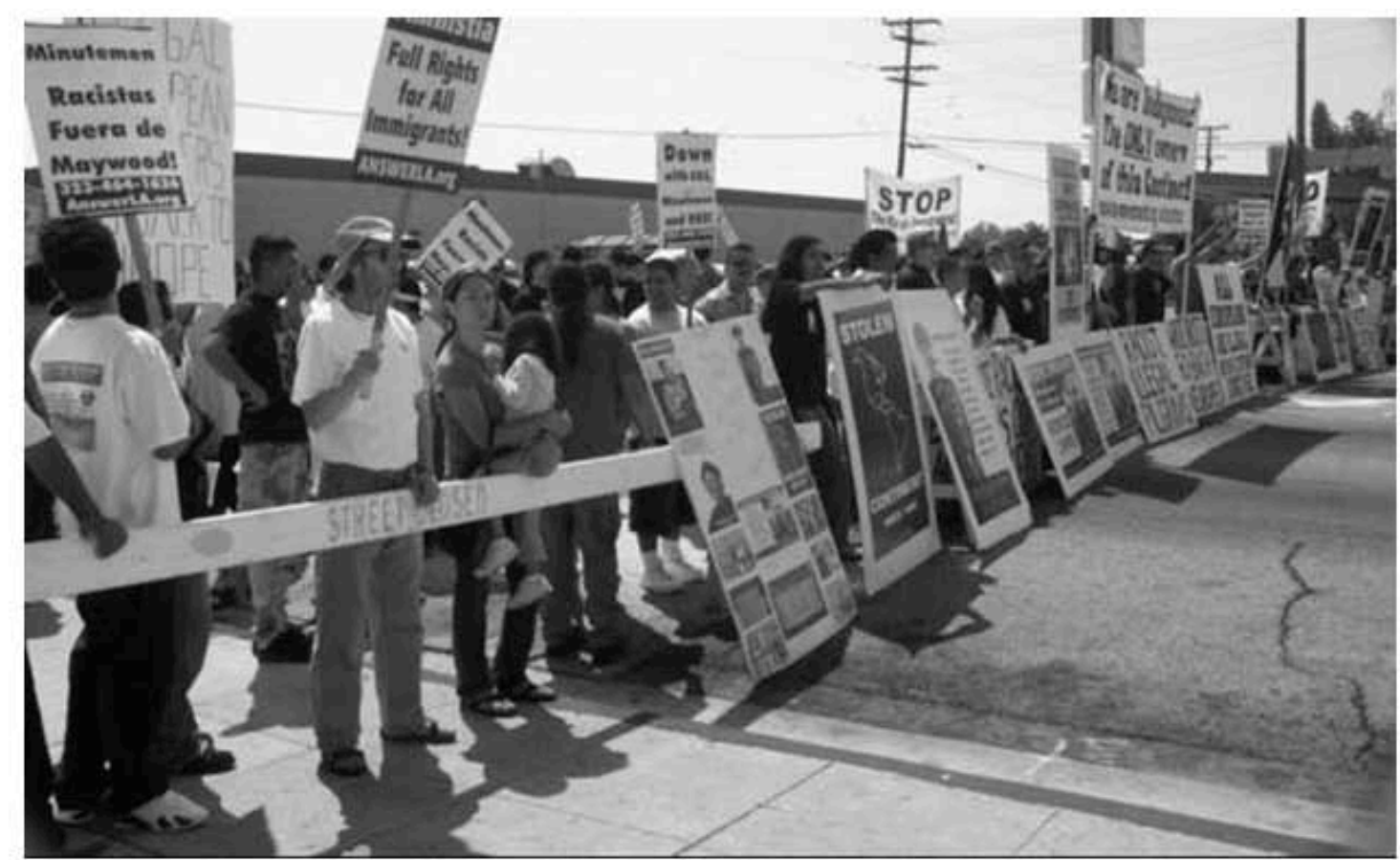

FIGURE 4

Immigrant Rights Demonstration in Maywood. Available at http://la.indymedia.org/news/ 2006/08/176057_comment.php\#215451.

the human rights of the individuals rather than on their legal status, and they generally prohibit local government employees from identifying, reporting, or detaining immigrants or otherwise doing the work of federal immigration officials in the absence of warrants" (ICMA, 2008). For instance, in San Francisco Mayor Newsom launched a Sanctuary City Outreach Campaign, and, in a highly publicized account, in Long Beach, CA, St. Luke's Episcopal Church provided refuge for Liliana Santuario (not her real last name) to prevent the breast-feeding mother from deportation to Mexico. These are part of the New Sanctuary Movement that has emerged as a response to a rescaling of immigrant enforcement to local governments (Bazar, 2007; Office of the Mayor [San Francisco], 2008). In this national movement, immigrants and their allies are demanding the Right to the Country, realized through the Rights to the City/Suburb.

\section{Contestation}

But Maywood's stand against anti-immigrant policies did not remain unchallenged. Former City Council member Sam Peña publicly disapproved of the city's opposition to federal law. According to Peña, "They talk about the city of no law and order, and I think Maywood is becoming that" (Becerra \& Winton, 2006). Similarly, a minority of residents came to City Council meetings to question Maywood's Sanctuary status (City of Maywood, 2006c). Some had a more extreme approach. After passing Resolution 5225, hate mail and death threats were sent to its main advocates, Councilmen Felipe Aguirre and Thomas Martin (Becerra \& Winton, 2006). It is unclear who supported former councilmember Peña or made the threats, but it is evident that at least a portion of Maywood's predominantly Latino residents opposed the progressive stance on immigration in the city. This reaction points to broader trends in which some Mexican Americans and authorized Mexican immigrants adopt anti-unauthorized immigrant positions in an effort to improve their own standing vis-a-vis the pressures they face regarding identity politics, assimilation, and managing interpersonal relationships with new neighbors (Gutierrez 1995; Ochoa, 2004; Geron, 2005; Pulido, 2009). 
Maywood was receiving national attention. As SOS, the Minutemen, and other nativist groups applauded Costa Mesa, even making the Mayor an honorary Minuteman member, anti-immigrant activists from Save Our State crossed county lines to stage a protest at Maywood's City Hall to "punish" the city by disrupting traffic and making the city pay for extra police time, costing Maywood an estimated $\$ 20,000$ to $\$ 30,000$ according to Mayor Thomas Martin (Baer, 2006; Rohrlich, 2006). SOS planned similar efforts in other predominantly Latino suburbs in the Los Angeles region, where they met with massive resistance from suburban immigrant supporters (Akers Chacón and Davis, 2006).When news of SOS's protest came out, immigrant activists began organizing a counter-protest already equipped with the networks created when campaigning against the traffic checkpoints. Organizers also used popular media such as MySpace to advertise the counter-rally. One post stated, "The racist group the Minute Men Project is coming this Saturday 26th to the city of Maywood to protest against the city's support for sanctuary to immigrants. Show your opposition to their radical and racist movement" (Black Misfit, 2006). Residents from adjacent suburbs in Southeast Los Angeles including Bell, Bell Gardens, Huntington Park, South Gate, Cudahy, and Lynwood were encouraged to attend. Concurrently, advocates met for mariachi music, lunch, and a citizenship workshop at Saint Rose of Lima Church (Rohrlich, 2006). In Maywood, the city, the region, and the nation intersected.

While some pro- and anti-immigrant activists claimed rights based on a nationstate, best exemplified when a U.S. flag was removed from the post office and replaced with a Mexican flag, many counter-protesters tied the demonstration to larger movements for collective rights divorced from notions of belonging to a nation-state. According to Council Member Sergio Calderón, "I believe that we were exercising our rights and fulfilling our responsibilities as local elected officials in voicing what the majority of our populace held in strong conviction" (Cuevas, 2006). He continued, "Proposed laws, such as HR 4437, are hypocritical in spirit and would accomplish nothing more than creating what would resemble a police state and deny dignity to those who perform our most hazardous and labor-intensive jobs" (Cuevas, 2006). For Councilmember Calderón, the needs of inhabitants, regardless of citizenship, are the main basis of governance. According to counter-protestor María Sauza, "They believe that they can tell people that they are illegals, when it's a human right to look for a better life."13 Héctor Carréon of $L a$ Voz de Aztlán echoed this sentiment, "All human beings, regardless of national origin, have the right to 'life, liberty and the pursuit of happiness.' The City of Maywood, CA, should be commended for guaranteeing this fundamental right to its residents of Mexican descent, regardless of their documentation status" (Cuevas, 2006). In Maywood, the dominant basis for rights is not found within the nation-state but instead determined by inhabitance. The movement in Maywood generated proactive measures such as a citizens' committee to oversee the police, the disbanding of the traffic division which ran the checkpoints, and the election of City Council members aligned with the political values of those targeted by the checkpoints. As a result of their efforts, we see increased participation at council meetings, bilingual publications, and a focus on quality of life struggles. These proactive measures suggest that their approach is indeed a Right to the Suburb claim for access to the community (and the ability to move freely within it) as well as a call for self-governance.

\section{CONCLUSION: A TALE OF TWO SUBURBS?}

Costa Mesa and Maywood have approached immigrant rights in divergent ways. This is not a simple matter of demographics. Instead, the cases of Costa Mesa and Maywood reveal an alternative vision of rights as the product of historical trajectories, activism, and political leadership. On the one hand, Costa Mesa has partnered with ICE in order to detain, process, and deport immigrants, authorized and unauthorized alike, for minor infractions such as jay walking and riding a bicycle without a helmet. But, while 
Costa Mesa has criminalized the very act of inhabiting the suburb, Maywood has defied the criminalization of its residents by taking stands against laws that criminalize immigrants, such as HR 4437 and the California Driver's License Bill. Each of these controversial moves depended in part on each suburb's particular socio-political histories, the election of City Council members with strong political leanings, and networks of activists who sustained an effective mobilization.

Throughout the United States, most suburbs have adopted an approach that falls between those exemplified by Costa Mesa and Maywood. According to a 2007 survey by International City/County Management Association of 500 local governments, 19\% "require local law enforcement officials to report unauthorized persons to federal authorities," $12 \%$ "require local law enforcement officials to obtain federal training on Immigration and Customs Enforcement," and fewer than 5\% of respondents have more radical approaches. Amongst these approaches include "designating the city as a sanctuary." The approach each city adopts is in part defined by City Councils but contested and shaped by residents. This contestation is most evident in resident-driven voting drives, public statements in City Council meetings, and demonstrations in symbolic public spaces, such as those in Costa Mesa and Maywood.

When thinking about the larger and lasting social, economic, political, and spatial implications of policies, actions, and cultural trends as related to immigration reform and Lefebvre's Right to the City in Southern California and U.S. society, at least three trends become particularly clear. First, this study suggests immigrant activism is increasingly being generated in suburbs, challenging the assumption that social movements originate in the city. This partnership, at times, draws on resources from the central city but sometimes organizes independently of the city by partnering with or following the example of neighboring suburbs. Second, election-based organizing and local activism can be a highly effective way to enact municipal level change (Vitiello, 2009). In Costa Mesa, approval to enter the partnership with ICE was passed after electing a majority antiimmigrant council, whereas in Maywood the most radical approaches to immigrant rights were passed after residents successfully campaigned for pro-immigrant rights council members. Lastly, seeking to expand or constrict the Right to the City/Suburb necessarily entails multi-scalar efforts. In Maywood and Costa Mesa, discrimination was enabled through intersecting municipal politics, state policies, and federal departments. Similarly, successful organizing efforts called on local organizations, regional networks of activists, and linkages with national discourses on immigration policy.

While divergent, the approaches of Maywood and Costa Mesa are not isolated from one another, but instead reveal a metropolitan level relationship. Each city has used the other to contrast and legitimize its position. For instance, Felipe Aguirre has stated that while immigrants may be attacked in Costa Mesa, they can feel safe in Maywood (Cienfuegos, 2006). In an opposing statement, Costa Mesa Councilmember Eric Bever has criticized Maywood for not enforcing federal laws and asked cities to follow Costa Mesa's example instead, arguing that "freedom does not mean without laws" (City of Costa Mesa, 2006b).While council members have crossed discursive borders, activists have crossed municipal, county, and state borders to participate in public demonstrations for and against immigrant rights. What both anti- and pro-immigrant activist hold in common is that at the center of the debate they are asking, who has a Right to the Suburb; who defines it, enforces it, and enjoys it; and how and to what effects?

This paper suggests a reexamination of the Right to the City as an analytical and mobilizing framework. In practice, this suggests a larger call for regional networks of activists fighting similar battles in a common call for expansion of immigrant rights and the Right to the City/Suburb.14 This means building networks and coalitions that argue for use value over exchange value, inhabitance as the basis for claims to political participation (rather than membership in the nation-state), and public spaces as contested sites that have the possibility to expand these claims. Furthermore, a Right to the Suburb framework with an emphasis on the new politics of settlement suggests new formations 
for pro-immigrant and pro-minoritized communities' activism that bridges multiscalar organizing efforts, builds alliances amongst diverse struggles over displacement,15 and focuses efforts in the suburb for some forms of activism, as a complement to the current model which focuses largely on cities. Through exploring how Lefebvre's concept of Right to the City and the new spatial distribution of immigrants can inform one another, this paper suggests an opening for a new politics of emancipatory change within the terrain of the neoliberalizing United States.

ACKNOWLEDGEMENTS: Earlier versions of this article were presented at: the Conference "Radical Urbanism Critical Discourse on the Right to the City," CUNY Graduate Center, City University of New York, December 12th, 2008; and "Diverse Suburbs: History, Politics, and Prospects," National Center for Suburban Studies, Hofstra University, October 22, 2009. The authors thank the anonymous reviewers and the Immigration and Integration Initiative 2007-2008 from the University of Southern California for its support.

\section{ENDNOTES}

1 In this article, we use the adjective "unauthorized" to refer to immigrants that are not legally permitted to be in the United States. We disavow the common adjectives "illegal" and "undocumented" to name these immigrants. In the former case, we acknowledge the right of human beings to migrate in search of better living conditions, and thus challenge the designation "illegal." In the latter case, many, if not most, unauthorized immigrants do carry identification documents of their countries of origin and hence are not undocumented.

2 We use the adjective "minoritized" to refer to ethnic groups traditionally considered minorities to signal the common perception and treatment as minorities they are subjected to even when they become majorities in certain areas.

3 The largest urban marches in recent years took place in 2006, protesting a heightened national anti-immigrant climate culminating in the HR 4437 proposal. Hundreds of thousands of immigrants and allies marched in Los Angeles, New York, Chicago, and many other U.S. cities. The events were amply covered by the media (Pulido, 2007).

4 This category includes movers from foreign countries, as well as movers from Puerto Rico, U.S. Island Areas, and U.S. minor outlying islands.

5 Of these immigrants, almost 50\% came from Latin American countries, with a large portion also coming from Asia (37\%). Latinos as a whole make up a much larger percentage of Costa Mesa residents than Asians and Asian Americans, perhaps further exacerbating concerns over Latino migration (32\% and $7 \%$, respectively). (Center for Demographic Research, 2003).

6 A U.S. gospel song that later became a popular protest song during the U.S. civil rights movement. Lyrics include "We shall overcome," "We'll walk hand in hand," and "We shall all be free" (Southern, 1971).

7 Lyrics include "God bless America, my sweet home." It is "America's unofficial national anthem," originally written by Serbian immigrant Irving Berlin in 1918 (Library of Congress, 2003, April 2).

8 The initial intent of the city had been to join the $287(\mathrm{~g})$ program, but the city settled with the Criminal Alien Program because 287(g) proved to be too much of a strain on personnel and finances.

9 This amendment to the Immigration and Nationality Act would strengthen enforcement of immigration law enforcement and intensify securitization of the border between the U.S. and Mexico. The most debatable and opposed part of the Border Protection, Antiterrorism and Illegal Immigration Control Act of 2005 (H.R. 4437) is that it would have made it a felony to reside in the U.S. without authorization and would have penalized those who assisted unauthorized immigrants, including churches and aid workers. It was 
strongly opposed by immigrant rights advocates, as evident in the wave of rallies in 2006 calling for more progressive immigration reform. H.R. 4437-109th Congress: Border Protection, Antiterrorism, and Illegal Immigration Control Act of 2005 (2005). In GovTrack.us (database of federal legislation). Retrieved December 5, 2010, from http://www.govtrack.us/congress/bill.xpd?bill=h109-4437.

10 For a brief history of traffic checkpoints occurring throughout the Los Angeles region and alternative legislation being proposed, see Cedillo (2004).

11 The Dream Act, or HR 513, would grant permanent resident status to immigrant minors who have (1) lived continuously in the United States, (2) are "of good moral character," and (3) have attained a certain degree of formal education (GovTrack.us. H.R. 5131-109th Congress, 2006).

12 The Clear Act, or HR 3137, was proposed in 2005 to authorize local and state enforcement to "investigate apprehend, or transfer to federal custody aliens in the United States." Furthermore, it would increase criminal penalties for immigration infractions (GovTrack.us. H.R. 3137-109th Congress, 2005).

13 Original text in Spanish states, "Creen que pueden decirle a la gente que son ilegales, cuando es un derecho de humanos buscar una vida major" (Ortega, 2006). See also Rocco (1997).

14 See Pastor, Benner, \& Matsuoka (2009) for more on regional social movements.

15 See TIDES (2007) for more on how the Right to the City Alliance is building national networks to fight displacement.

\section{REFERENCES}

Ahrens, E. W., \& Urbina, P. (2005). Images of America Maywood. Charleston. SC: Arcadia Publishing.

Akers Chac'on, J., \& Davis, M. (2006). No one is illegal: Fighting racism and state violence on the U.S.-Mexico border. Chicago: Haymarket Books.

Anderson, J. (2007, October 4). Mario's tow truck troubles. LA City Beat. Available at http://www.lacitybeat.com/cms/story/detail/?id=6276\&IssueNum=226 (accessed March 17, 2008).

Archibold, R. C. (2006, April 2). Latinos protest in California in latest immigration march. The New York Times. Available at http://www.nytimes.com/2006/04/02/us/02costamesa.html (accessed December 18, 2007 Arellano, G. (2008). Orange County: A personal history, I've been taking notes. New York: Scribners.

Barr, T. A. (1981). The story of Costa Mesa. Costa Mesa. CA: Press of City of Costa Mesa, California.

Baer, D. (2006, March 3). Legal affairs: Costa Mesa's immigration deputies, Part 2. Day to day. National Public Radio. Available at http://www.npr.org/templates/story/story.php?storyId=5243884 (accessed December 18, 2007).

Bazar, E. (2007, July 8). Illegal immigrants find refuge in holy places. USA Today.

Black Misfit (Username) (2006, August 25). The 'MinuteMen' are coming to Maywood, CA! Blog post. Available at Myspace.com (accessed May 4, 2008).

Blank, A. (2009, April 15). Mansoor declares seat bid. Daily Pilot. Available at http://www.dailypilot.com/articles/2009/04/15/topstory/dpt-mansoorforassembly 04162009.txt, accessed July 8, 2009.

Becerra, H., \& Winton, R. (2006, July 13). Hate mail, threats probed in Maywood. Los Angeles Times. Available at http://articles.latimes.com/2006/jul/13/local/me-hit13 (accessed March 30, 2008).

Cardenas, J. (2003, August 22). Police checks of cars halted. Los Angeles Times. Available at http://articles. latimes.com/2003/aug/22/local/me-maywood22 (accessed March 17, 2008). 
Carpio, G. (2009, March 28, 2009). Personal observation. Participation in Demonstration. Pomona: California on Indian Hill.

Caspa, H. (2008). Terror in the Latino barrio: The rise of the new right in local government. Santa Ana, CA: Seven Locks Press.

Cedillo, G. (2004) A social, public safety, and security: argument for licensing undocumented drivers. Center for Latin American Studies. CLAS Policy Papers. eScholarship Repository, University of California. Available at http://repositories.cdlib.org/clas/pp/2 (accessed May 14, 2009

Center for Demographic Research (2003) Orange County immigrants in 2000: An overview. Orange County Profile, 8(4).

Chang, P. (2007). The state of the region 2007: Measuring regional progress. Los Angeles: Southern California Association of Governments.

Cienfuegos, E. (2006, January 27). Alta California: The tale of two cities. La Voz de Aztlan. Available at http://www.aztlan.net/tale_of_two_cities.htm (accessed May 4, 2009).

City of Costa Mesa (2005, December 6). Minutes of regular meeting of the City Council: City of Costa Mesa.

City of Costa Mesa (2006a, January 3). Minutes of regular meeting of the City Council: City of Costa Mesa.

City of Costa Mesa (2006b, March 21). Minutes of regular meeting of the City Council: City of Costa Mesa.

City of Costa Mesa Planning Division (2007) Community economic profile. Costa Mesa, CA: Author.

City of Maywood (1998). History of Maywood webpage. Accessed June 12, 2008, from History of Maywood Folder. Cesar Chavez Library. Maywood. CA.

City of Maywood (2003a, August 12). Minutes of the regular meeting of the Maywood City Council.

City of Maywood (2003b, August 13). Minutes of the regular meeting of the Maywood City Council.

City of Maywood (2005a, November 29). Minutes of the regular meeting of the Maywood City Council.

City of Maywood (2005b, December 13). Minutes of the regular meeting of the Maywood City Council.

City of Maywood (2006a, January 10). Minutes of the regular meeting of the Maywood City Council.

City of Maywood (2006b, January 24). A resolution of the City Council of the City of Maywood, California, opposing the Clear act and the Sessenbrenner-King immigration restriction bill (H.R. 4437) being considered in Congress, and urging the United States Senate to reject it. Resolution No. 5225.

City of Maywood (2006c, February 14). Minutes of the regular meeting of the Maywood City Council.

City of Maywood (2006d, May 30). Minutes of the regular meeting of the Maywood City Council.

Cuevas, H. (Interviewer) (2006, September 7). The safe haven debate. In Life and Times. Transcript available at http://kcet.org/lifeandtimes/archives/200609/20060906.php (accessed May 4, 2008). KCET.

Del Olmo, F. (2003a, August 3). Maywood's mean money machine. Los Angeles Times. Available at http:// articles.latimes.com/2003/aug/03/opinion/oe-delolmo3 (accessed March 17, 2008).

Del Olmo, F. (2003b, August 17). Towing policy is not off the hook. Los Angeles Times. Available at http:// articles.latimes.com/2003/aug/17/opinion/oe-delolmo17 (accessed March 17, 2008).

Garcia, M. (2001). A World of its own: Race, labor, and citrus in the making of Greater Los Angeles, 1900-1970. Chapel Hill: University of North Carolina Press. 
Garcia-Bedolla, L. (2005). Fluid borders: Latino power, identity, and politics in Los Angeles. Berkeley: University of California Press.

Geron, K. (2005). Latino political power: Latinos exploring diversity and change. Boulder, CO: Lynne Rienner Publishers.

GovTrack.us, H.R. 3137-109th Congress (2005). CLEAR Act of 2005, GovTrack.us (database of federal legislation) <http://www.govtrack.us/congress/bill.xpd?bill=h109$3137 \&$ tab=summary $>$ (accessed May 5, 2009).

GovTrack.us, H.R. 5131-109th Congress (2006). American Dream Act, GovTrack.us (database of federal legislation) <http://www.govtrack.us/congress/bill.xpd?bill=h1095131> (accessed May 5, 2009).

GovTrack.us, H.R. 4437-109th Congress (2005). Border protection, anti-terrorism, and illegal immigration control act of 2005. GovTrack.us (database of federal legislation) <http://www.govtrack. us/congress/bill.xpd?bill=h109-4437\&tab=summary> (accessed May 5, 2009).

Gutierrez, D. (1995). Walls and mirrors: Mexican Americans, Mexican immigrants, and the politics of ethnicity. Berkeley: University of California Press.

HoSang, D. (2007).Racial propositions:Genteel apartheid in postwar California. University of Southern California. Dissertation.

International City/County Management Association (2008). Immigration reform: An intergovernmental imperative. Binghamton, NY: Binghamton University.

Irazábal, C. (Ed) (2008). Ordinary places, extraordinary events: Citizenship, democracy and public space in Latin America. New York: Routledge.

Irazábal, C., \& Dyrness, G. R. (2010). Promised land? Immigration, religiosity, and space in Southern California Space \& Culture, 13(4), 365-375.

Kotin, S., Dyrness, G. R., \& Iraz'abal, C. (forthcoming). Immigration and integration: The religious and politicalactivism of immigrants in Los Angeles. Progress in Development Studies.

Kruse, M., \& Sugrue, T. (2006) The new suburban history. Chicago: University of Chicago Press.

Lagorio, C. (2006, March 28). Costa Mesa's identity crisis: An O.C. city is getting tough on immigrants-and immigrants are fighting back. CBS News. Available at http://www.cbsnews.com/stories/2006/03/28/eveningnews/main1447962.shtml

(accessed January 8, 2008).

Lait, M., \& Glover, S. (2007, April 1). Maywood employs police officers with a history of trouble. Los Angeles Times. Available at http://articles.latimes.com/2007/apr/01/local/me-maywood1 (accessed July 9, 2009).

Lassiter, M. D. (2006). The silent majority: Suburban politics in the Sunbelt South. Princeton, NJ: Princeton University Press.

Leece, W. (2006). Biography: Wendy Brooks Leece. Available at wendy.leece.com (accessed June 10, 2008).

Lefebvre, H. (1996). Writings on cities. E. Kofman \& E. Lebas. (Trans.). Oxford: Blackwell. Li, W. (2006). From urban enclave to ethnic suburb: New Asian communities in Pacific Rim countries. Honolulu: University of Hawaii Press.

Library ofCongress (2003, April 2). God bless America. American treasures of the library of congress.Washington, DC. Available

http://www.loc.gov/exhibits/treasures/trm019.html (accessed May 4, 2008).

Linder, E.(Webmaster) (2006).Wendy Leece forCosta MesaCityCouncil homepage.Available atWendyleece.com (accessed July 15 2008).

Mansoor, A. (2006, October 11). An American without a hyphen. Available at allanmansoor.com/blog/?p=5 (accessed on April 12, 2008).

Mansoor, A. (2007, November 16). Illegal immigration. Available at http://allanmansoor.com/blog/?p = 6 .

Martinez, B. (2006, January 4). Arrest disrupts Costa Mesa council meeting. The Orange County

Register.

Available

at 
http://www.ocregister.com/ocregister/news/homepage/article929384.php (accessed March 10, 2008).

McGirr, L. (2002). Suburban warriors: The origins of the new American right. Princeton, NJ: Princeton University Press.

Miller, E. J. (1981). The SAAB story: The history of the Santa Ana army air base. Costa Mesa, CA: The Costa Mesa Historical Society and the SAAB Wing.

Mitchell, D. (2003). The right to the city: Social justice and the fight for public space. New York: Guilford Press.

Ngai, M. (2004). Impossible subjects: Illegal aliens and the making of modern America. Princeton, NJ: Princeton University Press.

Nicolaides, B. M. (2002). My blue heaven: Life and politics in the working-class suburbs of Los Angeles, 19201965. Chicago: University of Chicago Press.

Ochoa, G. L. (2004). Becoming neighbors in a Mexican American community: Power, conflict, and solidarity. Austin: University of Texas Press.

Office of theMayor (San Francisco) (2008, April 4). Mayor Newsom launches Sanctuary City outreach campaign. Press release. San Francisco.

Ortega, J. (2006, August 27). Santuario de protestas: Impulsores y detractores de los inmigrantes se encontraron en Maywood. La Opini'on.

Pak, E. (2009, December 15). Jury: Costa Mesa did not violate latino activist's rights. Orange County Register.

Pastor, M., Benner, C., \& Matsuoka, M. (Eds.) (2009). This could be the start of something big: How social movements for regional equity are reshaping metropolitan America. Ithaca, NY: Cornell University Press.

Pomona checkpoints: Saving lives or ruining lives (2009, May 26). Panel presentation given at California State

Polytechnic University, Pomona, hosted by the Multi-Cultural Council.

Pulido, L. (2000). Rethinking environmental racism: White privilege and urban development in Southern California Annals of the Association of American Geographers, 90(1), 12-40.

Pulido, L. (2007). A day without immigrants: The racial and class politics of immigrant exclusion. Antipode 39(1), 1-7.

Pulido, L. (2009). Immigration politics and motherhood. Amerasia Journal, 35(1), 169-178. Purcell, M. (2003). Citizenship and the right to the global city: Reimagining the capitalistworld order. International Journal of Urban and Regional Research, 27(3), 564590.

Radford, L. (2006, August 27). Maywood stops the invasion. Los Angeles Independent Media Center. Available http://la.indymedia.org/news/2006/08/176057.php (accessed June 3, 2009).

Raouf, N. (1999, July 20). Maywood officer is mourned. Los Angeles Times. Available at http://articles. latimes.com/1999/jul/20/local/me-57849 (accessed March 17, 2008).

Robinson, A. (2007, August 24). ICE traces illegal immigrants. Daily Pilot. Available at http://www. dailypilot.com/articles/2007/08/24/publicsafety/dpt-ice24.txt (accessed May 14, 2009).

Rocco, R. (1997). Citizenship, culture, and community: Restructuring in Southeast Los Angeles. In W. Flores\& R. Benamayor (Eds.) Latino cultural citizenship: Claiming identity, space, and rights. Boston: BeaconPress.

Rohrlich, T. (2006, August 27). Protest targets Maywood's stance. Los Angeles Times. Available at http://articles.latimes.com/2006/aug/27/local/me-protest27 (accessed at May 14, 2009).

Saito, L. T. (1998). Race and politics: Asian Americans, Latinos, and whites in a Los Angeles suburb. Urbana: University of Illinois Press.

Santana, N., \& Saavedra, T. (2007a, December 16). Crime little changed since deportation programs began. Orange County Register. Available at 
http://www.ocregister.com/article/immigrants-ice-immigration-1942524-illegal-year (accessed March 10, 2008).

Santana, N., \& Saavedra, T. (2007b, December 17). Felons found in police immigration screening. Orange County Register. Available at http://www.ocregister.com/articles/costa-mesa-crime-1942532-immigration-police (accessed March 10, 2008).

Sassen, S. (2006). The repositioning of citizenship: Emergent subjects and spaces for politics. Berkeley Journal of Sociology, 46, 4-25.

Schachter, J. P., Franklin, R. S., \& Perry, M. J. (2003). Migration and geographic mobility in metropolitan and nonmetropolitan America: 1995 to 2000. Census 2000 Special Reports. United States Census 2000. Available at http://www.census.gov/prod/2003pubs/censr9.pdf

Serna, J. (2008, September 17). Report: Chief against ICE. Daily Pilot. Available at http://www.dailypilot. com/articles/2008/10/27/topstory/dpt-iceopposition091808.txt (accessed July 8, 2009).

Singer, A. (2004, February). The rise of new immigrant gateways. Washington, DC: The Brookings Institution Press.

Singer, A., Hardwick, S. W., \& Brettell, C. B. (Eds.) (2008). Twenty-first century gateways: Immigrant incorporation in suburban America. Washington, DC: Brookings Institution Press.

Southern, E. (1971). The music of Black Americans: A history (2nd ed.). New York: W. W. Norton

TIDES Foundation (2007). The right to the city: Reclaiming our urban centers, reframing human rights, and redefining citizenship: A conversation between donor activist Connie Cagampang Heller and Gihan Perera of the Miami Workers Center. San Francisco: Author.

Traux, E. (2006, May 15). Maywood la ciudad santuario. La Opini'on.

U.S. Census Bureau (2000). Profile of selected economic characteristics: Maywood, CA. Available at

http://factfinder.census.gov/servlet/SAFFFacts?_event=\&geo_id=16000US0646492\&_geo Context=01000US\%7C04000US06\%7C16000US0646492\&_street=\&_county=maywood \&_ cityTown=maywood \&_state $=$ \&_zip $=$ \&_lang $=$ en \&_sse $=$ on $\&$ ActiveGeoDiv $=$ \&_useEV $=$ \&pctxt $=$ fph\&pgsl=160\&_submenuId=factsheet_1\&ds_name=ACS_2007_3YR_SAFF\&_ci_nbr=null\&q r_name=null\&reg=null\%3Anull\&_keyword $=$ \&_industry $=$.

U.S. Census Bureau (2005-2007). Selected economic characteristics: California. Accessed October 5, 2008, at http://factfinder.census.gov/servlet/ADPTable?_bm=y\&geo_id=04000US06\&-qr_name=ACS_2007_3YR_G00_DP3YR3 $\&$-context=adp\&-ds_name $=\&-$ tree_id $=3307 \&$-_lang=en \&-redoLog=false \&-format $=$.

U.S. Immigration and Customs Enforcement, Department of Homeland Security (2007, December 13). ICE program at Costa Mesa jail nets more than 500 deportable.

U.S. Immigration and Customs Enforcement, Department of Homeland Security (2009a, May 19). Delegation of immigration authority section 287(g). Immigration and Nationality Act.

U.S. Immigration and Customs Enforcement, Department of Homeland Security (2009b, August 28). ICE access

Varsanyi, M. (2008). Rescaling the 'alien,' Rescaling personhood: Neoliberalism, immigration, and the state. Annals of the Association of American Geographers, 98:(4), 877896.

Vázquez-Castillo, M. T. (2009). Anti-immigrant, sanctuary and repentance cities. Progressive Planning, 178, 10-13.

Vitiello,D. (2009). The migrantmetropolis andAmerican planning. Journal of the American Planning Association, 75(2), 245-255.

Watchdog (Username). Coyotl Tezcatlipoca gets arrested. Costa Mesa, CA. Filmed January 3, 2006. Available at http://www.youtube.com/watch?v=X5ANH_Z0Uzc, accessed May 4, 2008. 
Wiese, A. (2004). Places of their own: African American suburbanization in the twentieth century. Chicago: University of Chicago Press. 